\title{
Isolated Rafts from Adriamycin-Resistant P388 Cells Contain Functional ATPases and Provide an Easy Test System for P-glycoprotein-Related Activities
}

\author{
Karsten Bucher, ${ }^{1}$ Camille A. Besse, ${ }^{1}$ Sarah W. Kamau, ${ }^{1}$ Heidi Wunderli-Allenspach, ${ }^{1}$ and Stefanie D. Krämer ${ }^{1,2}$
}

Received October 1, 2004; accepted November 29, 2004

$\overline{\text { Purpose. } \text { P-glycoprotein (P-gp), a membrane ATPase expelling many structurally unrelated compounds }}$ out of cells, is one of the major contributors to multidrug resistance. It is enriched in cold TritonX-100 insoluble membrane domains (i.e., rafts). The purpose of this work was to characterize the ATPase activities of raft preparations from P388 cells overexpressing P-gp (P388/ADR) or devoid of P-gp (P388) and to establish a P-gp-enriched screening system for P-gp-interfering compounds.

Methods. Rafts were extracted with cold TritonX-100. The ATPase activity was characterized in 96-well plates using a fluorescence assay.

Results. The ATPase activity per mg protein was about five times higher in P388/ADR rafts than in crude membranes. The anti-P-gp antibody C219 inhibited 20\% of the activity in P388/ADR rafts but only about $10 \%$ of the activity in P388/ADR crude membranes and had no effect on the activity of P388 rafts. The known P-gp-activating compounds verapamil, progesterone, and valinomycin revealed the typical bell-shaped activity/concentration profiles in P388/ADR rafts, indicative for activation at low compound concentrations and inhibition at concentrations $>10$ to $100 \mu \mathrm{M}$. The inhibitory effect was also observed in P388 rafts.

Conclusions. Extracted rafts are rich in functional ATPases. Rafts from P-gp-overexpressing cells display P-gp-typical ATPase activity and provide an easy, P-gp-enriched screening system.

KEY WORDS: rafts; ATPase activity; P-glycoprotein; screening assay; verapamil.

\section{INTRODUCTION}

P-glycoprotein (P-gp) is the most extensively studied efflux protein involved in multidrug resistance. It is classified as an ATPase belonging to the ABC (ATP-binding cassette) superfamily of membrane transporters. It is characterized by 12 putative membrane-spanning domains, two Walker regions corresponding to the two ATP binding sites, and posttranslational modifications comprising phosphorylation and glycosylation. P-gp has been described to reduce the intracellular level of a large number of structurally unrelated lipophilic compounds including numerous cell toxic agents. Under physiologic conditions, it is mainly expressed in barrier cells such as epithelial cells of the gastrointestinal tract or endothelial cells of the brain and testes (1). However, P-gp expression is upregulated in different types of tumor cells upon treatment with chemotherapeutic agents, which often results in a generalized chemotherapy resistance of the tumors.

\footnotetext{
${ }^{1}$ Institute of Pharmaceutical Sciences, Department of Chemistry and Applied Biosciences, ETH, Federal Institute of Technology, Zürich, Switzerland.

${ }^{2}$ To whom correspondence should be addressed. (e-mail: skraemer@pharma.ethz.ch)

ABBREVIATIONS: ADP, adenosine diphosphate; ATP, adenosine triphosphate; BSA, bovine serum albumin; DTT, dithiothreitol; P-gp, P-glycoprotein; SDS-PAGE, sodium laurylsulfate-polyacrylamide gel electrophoresis.
}

As has been shown, P-gp has a basal ATPase activity in absence of xenobiotics (1), indicating that P-gp has a physiologic function beyond the removal of toxic entities. In the presence of exogenous substrates, modulators, and inhibitors, the ATPase activity is changed. It is assumed that P-gp recognizes substrates and modulators within the cytosolic leaflet of the plasma membrane (1) or in the cytosol (2). Substrates are transported either to the outer membrane leaflet or to the extracellular space. Modulators, also named reversing agents or chemosensitizers, inhibit the P-gp-driven substrate efflux out of the cell. There is evidence that modulators compete with the substrates for the binding sites and, although being translocated by the protein as indicated by a stimulation of the ATPase activity, their net flux remains unchanged due to a simultaneously occurring, P-gp-independent fast permeation of the compound (3).

There have been many attempts to unravel the structural patterns that are recognized by this so-called efflux pump (4-9). However, no clear structural characteristics to be screened for in drug libraries have emerged so far to identify substrates or modulators with a low failure rate. Considering the current trend to look for rather unspecific structure similarities (6) and seen the huge number of P-gp-interfering agents, the bottleneck lies clearly in the availability of sufficiently large data bases of experimentally confirmed substrates and modulators.

Biologic assays for the identification of P-gp-interfering 
compounds are therefore needed in drug development and to generate data bases to feed the in silico approach $(10,11)$. Different types of assays are currently used to identify and characterize compounds that interact with P-gp. Transport studies across tight monolayers of P-gp-overexpressing cells and efflux or influx studies with such multidrug-resistant cells allow to identify P-gp substrates, modulators, or inhibitors. In a different approach, fluorescent probes have been used as indicators of conformational changes of P-gp upon binding of substrates, modulators, or inhibitors (12), and Landwojtowicz et al. (13) developed a screening method for P-gp interaction based on the translocation-induced $\mathrm{pH}$-change in the extracellular microenvironment of cultured cells. A straightforward option to identify P-gp-interfering compounds is to directly measure the ATPase activity of P-gp allowing relatively high throughput of compounds. The analytics in ATPase assays are independent of the tested compounds while for transport assays the compounds have to be individually quantified $(10,14)$. ATPase assays identify substrates, modulators, and inhibitors in one run, though without distinguishing between them. In transport assays, substrates and modulators or inhibitors, respectively, have to be screened in separate assays, the latter two in presence of a known substrate. ATPase assays can be performed with material that can be prepared in advance and be stored and shipped, whereas transport assays generally require living cells in the assay. ATPase assays have been developed with different membrane fractions such as enriched plasma membranes (15), crude membranes (11), and enriched microsomal membranes (16). In addition, the ATPase activity of purified P-gp was studied after reconstitution of P-gp into proteoliposomes $(17,18)$.

$\mathrm{P}$-gp has been found to be located in detergent-insoluble, glycosphingolipid and cholesterol rich membrane domains, the so called rafts (19-23), together with several other membrane proteins that are involved in cell signaling (24). It remains open whether these proteins display their intrinsic activity in isolated rafts. If so, these preparations could be used to specifically study protein functions on isolated membrane domains. In this work, we show that cold 1\% TritonX-100 insoluble membrane domains from P-gp-overexpressing P388/ADR cells prepared by the method of Brown and Rose (25) display P-gp-specific ATPase activity which is responsive to known P-gp substrates, modulators, and inhibitors. With this well-defined source of P-gp, we established an ATPase assay to screen for compounds interfering with P-gp.

\section{MATERIALS AND METHODS}

\section{Chemicals}

Adenosine triphosphate, di-Na ${ }^{+}$(ATP) \#A2383, adenosine diphosphate, di- $\mathrm{Na}^{+}$(ADP) \#A2754, cyclosporin A \#30024, indomethacin \#I7378, orthovanadate, $\mathrm{Na}^{+}$\#S6508, progesterone \#P0130, ( \pm -propranolol \#P0884, valinomycin \#V0627, and ( \pm )-verapamil \#V4629 were purchased from Sigma (Buchs, Switzerland). Bovine serum albumin (BSA) \#05480, dithiothreitol (DTT) \#43815, NADH \#43420, ouabain \#75640, phosphoenolpyruvate \#79418, and pyruvate kinase \#83330 were from Fluka (Buchs, Switzerland) and ${ }^{3} \mathrm{H}$ TritonX-100 \#ART892 from ARC (American Radiolabeled Chemicals, St. Louis, MO, USA). Lactate dehydrogenase \#127876 and the protease inhibitor cocktail Complete were supplied by Roche Diagnostics (Basel, Switzerland). All other chemicals were of analytical grade.

\section{Cell Cultures and Antibodies}

P388 cells were purchased from the Japan Health Science Research Resources Bank (Osaka, Japan) and P388/ADR cells from the National Cancer Institute (Frederick, MD, USA). Cells were grown in suspension in RPMI1640 medium (Invitrogen Corp., Basel, Switzerland) containing 10\% heatinactivated fetal bovine serum and split 1:10 every 3 to 4 days. The monoclonal mouse antihuman P-gp antibody C219, antihuman CD44 antibody and antihuman placental alkaline phosphatase antibody were supplied by DAKO Corp (DakaCytomation, Carpinteria, CA, USA).

\section{Preparation of Rafts}

Rafts were prepared as described by Brown and Rose (25) with slight modifications. About $10^{9}$ cells (150 to $200 \mathrm{mg}$ protein) were incubated for $20 \mathrm{~min}$ with $2 \mathrm{ml} \mathrm{TNE} / \mathrm{TX}-100$ buffer [ $25 \mathrm{mM}$ Tris, $150 \mathrm{mM} \mathrm{NaCl}, 5 \mathrm{mM}$ EDTA, and Complete, $\mathrm{pH} 7.4$ (TNE), containing 1\% (v/v) TritonX-100] on ice and homogenized with 50 strokes at $1000 \mathrm{rpm}$ using a Dounce homogenizer. The homogenate was transferred to an equal volume of $80 \%(\mathrm{w} / \mathrm{v})$ sucrose in TNE into a centrifuge tube and overlaid with $2 \mathrm{ml}$ each of $30 \%, 20 \%, 10 \%$ and $1.5 \mathrm{ml}$ of $5 \%$ sucrose in TNE. After centrifugation at $200,000 \times g$ for 19 $\mathrm{h}$ at $4^{\circ} \mathrm{C}$ in a SW41Ti rotor (Beckman Instruments, Fullerton, CA, USA), rafts were visible as a turbid band in the upper part of the centrifuge tube corresponding to a density range between 1.04 and $1.09 \mathrm{~g} / \mathrm{cm}^{3}$ as determined from the refractive indices (refractometer from Bellingham and Stanley, Turnbridge Wells, UK). Fractions of $1 \mathrm{ml}$ were collected from the top of the tube (fractions 1 to 11). Quantification of total protein was performed with the DC protein assay kit from Bio-Rad (Hercules, CA, USA), which is based on the method of Lowry (26) using BSA as standard. The pooled raft fractions 4 to 6 contained about $0.3 \mathrm{mg}$ protein. Aliquots were stored at $-20^{\circ} \mathrm{C}$.

Thin layer chromatography analysis of the lipids revealed that the raft fraction was enriched in cholesterol (unesterified) as compared to the total cell lysate and the cold TritonX-100 soluble fraction. Rafts contained about 37\% ( $\mathrm{mol} / \mathrm{mol}$ of total lipids) cholesterol while cholesterol accounted for about $30 \%$ in the total cell extracts and for about $23 \%$ in the soluble fraction (data not shown).

The hydrodynamic mean diameter of the isolated rafts was analyzed using a Malvern Zetasizer 3000 HSA. Raft fractions typically showed average mean diameters between 240 and $280 \mathrm{~nm}$ with polydispersity indices between 0.4 and 0.5 , indicating a broad size distribution. No aggregates or precipitates were detectable from the correlogram.

The pooled raft fractions contained $6.5 \mu \mathrm{M}$ residual TritonX-100, as estimated from a preparation with $2 \mathrm{MBq}{ }^{3} \mathrm{H}-$ TritonX-100. Additional TritonX-100 up to a total concentration of $16.5 \mu \mathrm{M}$ had no influence on the basal ATPase activity of P388/ADR rafts. At a concentration of about $100 \mu \mathrm{M}$ TritonX-100 the activity was reduced to about $50 \%$.

\section{Preparation of Crude Membranes}

Crude membranes of P388 and P388/ADR cells were prepared according to (11) using ATPase buffer (50 mM Tris, $6 \mathrm{mM} \mathrm{MgCl} 2,0.5 \mathrm{mM}$ EDTA, pH 7.4) containing Complete 
and $1 \mathrm{mM}$ DTT. The crude membrane fraction prepared from $4 \times 10^{8}$ cells (60 to $80 \mathrm{mg}$ protein) contained about $0.8 \mathrm{mg}$ protein. Aliquots were stored at $-20^{\circ} \mathrm{C}$ before the ATPase assays.

\section{SDS-PAGE and Immunoblotting}

Protein patterns and P-gp contents were analyzed by sodium laurylsulfate-polyacrylamide gel electrophoresis [SDSPAGE $(7.5 \%$ SDS)] with subsequent silver staining (BioRad) or immunoblotting with the anti-P-gp antibody C219 (14). For SDS-PAGE, the fractions of the density gradient were diluted to $3 \mathrm{ml}$ with TNE and centrifuged at 250,000 $\times g$ for $3.5 \mathrm{~h}$ at $4^{\circ} \mathrm{C}$ to pellet the soluble proteins and the rafts, respectively. The pellets were resuspended in $100 \mu$ l electrophoresis buffer and analyzed as described above.

\section{Kinetic Assay}

ATPase activities were determined in 96 well plates (Corning, flat bottom, black, \#3915, Corning, Acton, MA, USA) with a total sample volume of $200 \mu \mathrm{l}$ per well using a modified protocol of Ref. (27). Between 6 and $12 \mu$ l of the pooled raft fractions from the density gradient, containing 1 $\mu \mathrm{g}$ protein, or crude membranes corresponding to $5 \mu \mathrm{g}$ protein, respectively, were mixed with ATPase buffer containing $0.5 \mathrm{mM}$ phosphoenolpyruvate (a stock solution was first adjusted to pH 7.4 with $\mathrm{NaOH}), 225 \mu \mathrm{M}$ NADH, $30 \mathrm{U} / \mathrm{ml}$ pyruvate kinase, $44 \mathrm{U} / \mathrm{ml}$ lactate dehydrogenase, $1 \mathrm{mM}$ DTT, and the compound to be tested. The $\mathrm{pH}$ of the mixture was checked and the plate was shaken and incubated at $37^{\circ} \mathrm{C}$ for $15 \mathrm{~min}$ before the start of the experiment. At time zero, $30 \mu \mathrm{l}$ of $60 \mathrm{mM}$ ATP in ATPase buffer adjusted to $\mathrm{pH} 7.4$ with $\mathrm{NaOH}$ were added to the wells using the injector of the plate reader (Synergy HT Bio-Tec, Winooski, VT, USA). Fluorescence was measured every $75 \mathrm{~s}$ for $2 \mathrm{~h}$ (excitation and emission at 340 and $460 \mathrm{~nm}$, respectively). At the end of the experiment, the $\mathrm{pH}$ was checked again to exclude any effects by $\mathrm{pH}$ changes on the activity measurements. The NADH concentrations were calculated from the fluorescence using an $\mathrm{NADH}$ calibration curve and ATPase activities were calculated from the linear range of the NADH concentration/time profiles, typically between 20 and $120 \mathrm{~min}$. Oxidation of $1 \mathrm{~mol}$ NADH corresponds to the hydrolysis of 1 mol ATP. Values corresponding to the NADH decrease in control samples without rafts were subtracted from the measured ATPase activities (typically about $10 \%$ ). The assay was optimized for our experimental conditions regarding $\mathrm{pH}$ stability and excess of ADP recycling enzymes, substrates and cofactors.

DTT, Complete, and sucrose in the concentrations used had no effect on the basal ATPase activity. For all compounds tested in the ATPase assay no influence on the size distribution of the rafts was observed for the concentration range used. As tested with ADP as a substrate, verapamil had no effect on the activity of the ADP recycling enzymes at all tested concentrations.

\section{Data Analysis}

The kinetics of the ATPase as a function of the ATP concentration were analyzed with the Michaelis-Menten equation with $K_{M}$ as the Michaelis-Menten constant and $V_{\max }$ as the maximal activity (28):

$$
v=\frac{V_{\max }[A T P]}{K_{M}+[A T P]}
$$

The apparent activities $V_{a p p}$ in the presence of effectors (activators or inhibitors) were fitted from the $V_{a p p} /$ concentration profiles (28).

For all activators, the profiles of $V_{a p p}$ vs the logarithm of the concentrations were bell-shaped, indicative for activation at low concentrations and inhibition of activity or loss of activation at higher concentrations. Data were fitted as follows:

$$
V_{a p p}=V_{\text {basal }}+\frac{V^{\prime} x}{K+x+\frac{x^{2}}{K_{i}}}
$$

$V^{\prime}$ denotes the difference between the activity at an effector concentration $x \rightarrow \infty$ if no loss of activating effect or inhibition occurred, and the basal activity $V_{\text {basal }}$ without effector. $K$ is the apparent dissociation constant of the enzyme/effector complex. $K_{i}$ describes the apparent dissociation constant of the inhibiting activator molecule from the enzyme/activator complex.

A decrease in activity was consistently observed at activator concentrations $>100 \mu \mathrm{M}$ (propranolol $>130 \mu \mathrm{M}$ ). For the determination of the activator parameters $V_{a p p}$ and $K$, alternatively, activator concentrations $>100 \mu \mathrm{M}(>130 \mu \mathrm{M}$ for propranolol) were ignored for the fitting and Eq. (3) was used instead of Eq. (2):

$$
V_{a p p}=V_{\text {basal }}+\frac{V^{\prime}}{1+\frac{K}{x}}
$$

The same equation was also used for the true inhibitors tested. It can alternatively be written as Eq. (4) (28):

$$
V_{a p p}=V_{\text {basal }}+V^{\prime}-\frac{V^{\prime}}{1+\frac{x}{K}}
$$

and reveals negative values for $V^{\prime}$ corresponding to the inhibitory effect (i.e., the difference between the basal activity and the residual activity at $x \rightarrow \infty$ ).

For clarity, most fits are shown in plots with a logarithmic concentration scale. Data were fitted using the Excel Solver tool. The $95 \%$ confidence intervals of the fits were calculated according to Ref. (29).

\section{RESULTS}

\section{Isolation and Characterization of Rafts from P388/ADR and P388 Cells}

Rafts from P388/ADR and P388 cells were prepared as described in "Materials and Methods." After the density gradient centrifugation of the cold TritonX-100 treated cells, the density fractions containing protein (fractions 4 to 11) were analyzed by SDS-PAGE and immunoblotting. Blotting with the monoclonal P-gp antibody C219 revealed enhanced levels of P-gp in the raft fractions (fractions 4 to 6) as compared to the fractions with higher densities containing the TritonX-100 soluble proteins (Fig. 1A). Analysis of the total cell lysate and rafts prepared from P-gp-devoid P388 cells (the latter not shown) revealed similar protein patterns but no detectable 


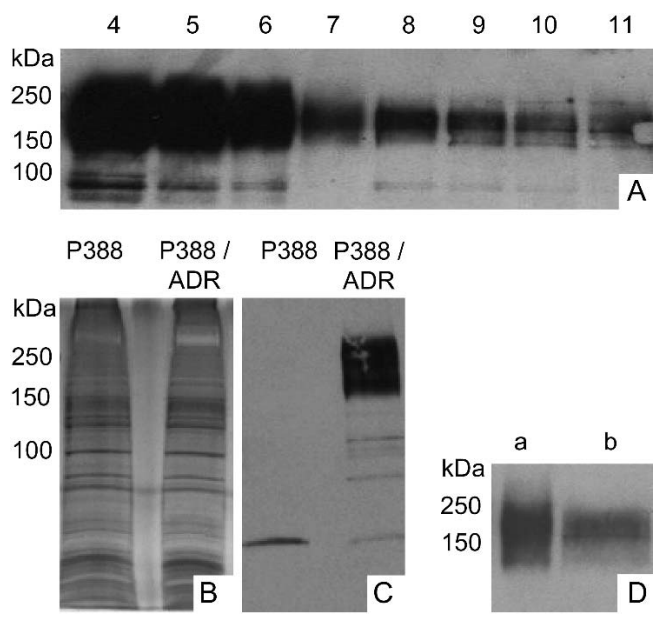

Fig. 1. P-gp enrichment in $P 388 / A D R$ rafts. (A) The proteincontaining fractions of the density gradient of cold TritonX-100 treated P388/ADR cells were analyzed by Western blotting with the monoclonal P-gp antibody C219. Of each fraction, $5 \mu \mathrm{g}$ protein were loaded on the gel. Fractions 4 to 6 correspond to the raft fractions. (B) Silver stain and (C) Western blot of the total cell lysates of P388 and P388/ADR cells (5 $\mu \mathrm{g}$ protein each). (D) Western blot and immuno staining with $\mathrm{C} 219$ of rafts (a) and crude membranes (b) prepared from P388/ADR cells. (a) $2.5 \mu \mathrm{g}$ protein, (b) $25 \mu \mathrm{g}$ protein. The ratio of the integrated optical densities of the two bands is about 1.2 as estimated using the software Scion Image (Scion Corporation).

amounts of P-gp on the immunoblot (Fig. $1 \mathrm{~B}$ and C). The comparison of the immunoblots of a representative P388/ ADR raft preparation with the crude membrane preparation of the same cell type (Fig. 1D) shows that rafts contain about 12 times more P-gp per mg protein than crude membranes.

\section{Kinetics of the ATPase Activity in P388/ADR Rafts}

The total ATPase activity of the raft preparations of P388/ADR cells was determined at different ATP concentrations up to $14 \mathrm{mM}$. Activities followed a Michaelis-Menten function up to about $10 \mathrm{mM}$ ATP (Fig. 2). At higher concentrations, the Michaelis-Menten conditions were not maintained. The fitted apparent $K_{M}$ value [see "Materials and Methods," Eq. (1)] for the ATP concentration range between

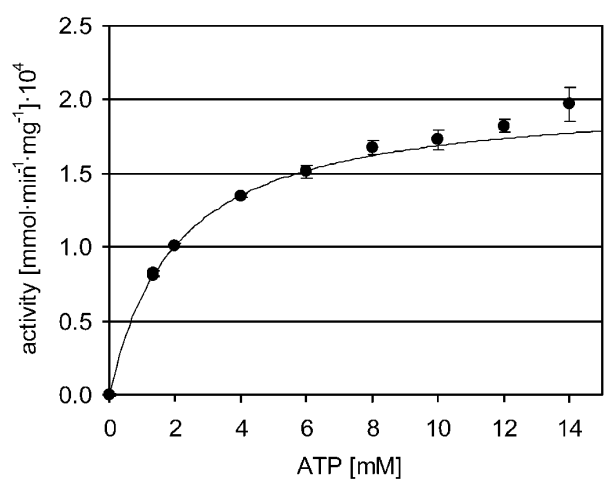

Fig. 2. ATPase activity of P388/ADR rafts. ATPase activities of P388/ADR rafts were determined at different ATP concentrations at $37^{\circ} \mathrm{C}, \mathrm{pH}$ 7.0. A representative experiment is illustrated with mean values and standard deviations from three wells each. The line shows the fitted Michaelis-Menten function with $K_{M} 2.0 \mathrm{mM}$ and $V_{\max } 2.0 \times$ $10^{-4} \mathrm{mmol} \mathrm{min}^{-1}$ per $\mathrm{mg}$ protein.
0 and $10 \mathrm{mM}$ was $2.0 \mathrm{mM}$. As a consequence, the ATP concentration for all assays was fixed at $9 \mathrm{mM}$. This concentration is far above the published $K_{M}$ values for P-gp, that is, 0.3 to $1.1 \mathrm{mM}(30)$.

\section{Differentiation Between P-gp-related and Other ATPase Activities}

Similar basal ATPase activities were determined in raft preparations from P388/ADR $\left(1.53 \pm 0.33 \times 10^{-4} \mathrm{mmol} \mathrm{min}^{-1}\right.$ per $\mathrm{mg}$ total protein; $\mathrm{n}=33)$ and P388 cells $(1.34 \pm 0.28 \times$ $10^{-4} \mathrm{mmol} \mathrm{min}^{-1}$ per $\mathrm{mg}$ total protein; $\left.\mathrm{n}=21\right)$. ATPase activities in the same range were also found for rafts of MDCK cells (Madin Darby Canine Kidney cells, a cell line with an epithelial phenotype growing to confluent monolayers) and for rafts of the P-gp-transfected MDCK cells, that is, mdr1-MDCK cells (data not shown). For crude membranes of P388/ADR cells, the basal activity was about 5 times lower than in P388/ADR rafts, that is, $3.2 \pm 0.9 \times 10^{-5} \mathrm{mmol} \mathrm{min}^{-1}$ per $\mathrm{mg}$ total protein; $\mathrm{n}=3$.

To characterize further the ATPase activity of the raft preparations of P388/ADR and P388 cells, the influence of known ATPase inhibitors was investigated. Results originating from data fitting with Eq. (3) are expressed as residual activities (i.e., \% of the basal activity). Confidence intervals of the fitted activities at $\alpha 0.05$ are shown in brackets. The mouse monoclonal P-gp antibody C219, which was described to reduce the ATPase activity of a plasma membrane enriched fraction of a P-gp positive tumor cell line (15), decreased the activity of P388/ADR rafts to $79.8 \pm 2.2 \%$ between 0.67 and $2.50 \mu \mathrm{g}$ antibody per $\mathrm{ml}$ and $5 \mu \mathrm{g}$ raft proteins per $\mathrm{ml}$. The fitted residual relative activity at infinite antibody concentration is $72.2 \%(4.4 \%)$. C219 had no significant influence on the ATPase activity of P388 rafts ( 98\% (3.6\%)) (Fig. 3A). With crude membranes $(25 \mu \mathrm{g} / \mathrm{ml})$ prepared from P388/ADR cells, the C219 antibody reduced the ATPase activity to $90.0 \pm$ $1.2 \%$ between 1 and $7.5 \mu \mathrm{g}$ antibody per ml. Placental alkaline phosphatase antibody and CD44 antibody were used as negative controls. Both of them had no inhibitory effect on the ATPase activity of P388/ADR rafts (data not shown). Figure $3 \mathrm{~B}$ shows the influence of orthovanadate, a known inhibitor of various types of ATPases $(31,32)$, on P388/ADR and P388 rafts. In both cases, the activity was similarly reduced in a concentration-dependent manner. At $0.05 \mu \mathrm{M}$ orthovanadate, about $10 \%$ inhibition was observed and highest inhibition was obtained at concentrations $>5 \mu \mathrm{M}$. The residual activity calculated from the fit value was $31.1 \%(3.2 \%)$ for the P388/ADR rafts and $48.4 \%$ (4.7\%) for the P388 rafts. Ouabain, an inhibitor of the $\mathrm{Na}^{+} / \mathrm{K}^{+}$-ATPase, was tested in concentrations up to $400 \mu \mathrm{M}$. A reduction in ATPase activity to $88.9(3.8 \%)$ and to $93.7 \%(6.0 \%)$, respectively, was found in the raft preparations of P388/ADR and P388 cells (Fig. $3 C$ ). This indicates that about $90 \%$ of the observed activity originates from other ATPases than the $\mathrm{Na}^{+} / \mathrm{K}^{+}$-ATPase. $\mathrm{Cy}$ closporin $\mathrm{A}$ is frequently used as a $\mathrm{P}$-gp inhibitor for in vivo and in vitro experiments. We found a concentrationdependent inhibition of the ATPase activity in both P388/ ADR and P388 rafts (Fig. 3D). At $0.2 \mu \mathrm{M}$, the reduction was between $5 \%$ and $6 \%$ in both types of rafts. The residual activity as determined from the fit value was $60.0 \%$ (4.7\%) for $\mathrm{P} 388 / \mathrm{ADR}$ rafts and $70.6 \%(8.1 \%)$ for $\mathrm{P} 388$ rafts. 

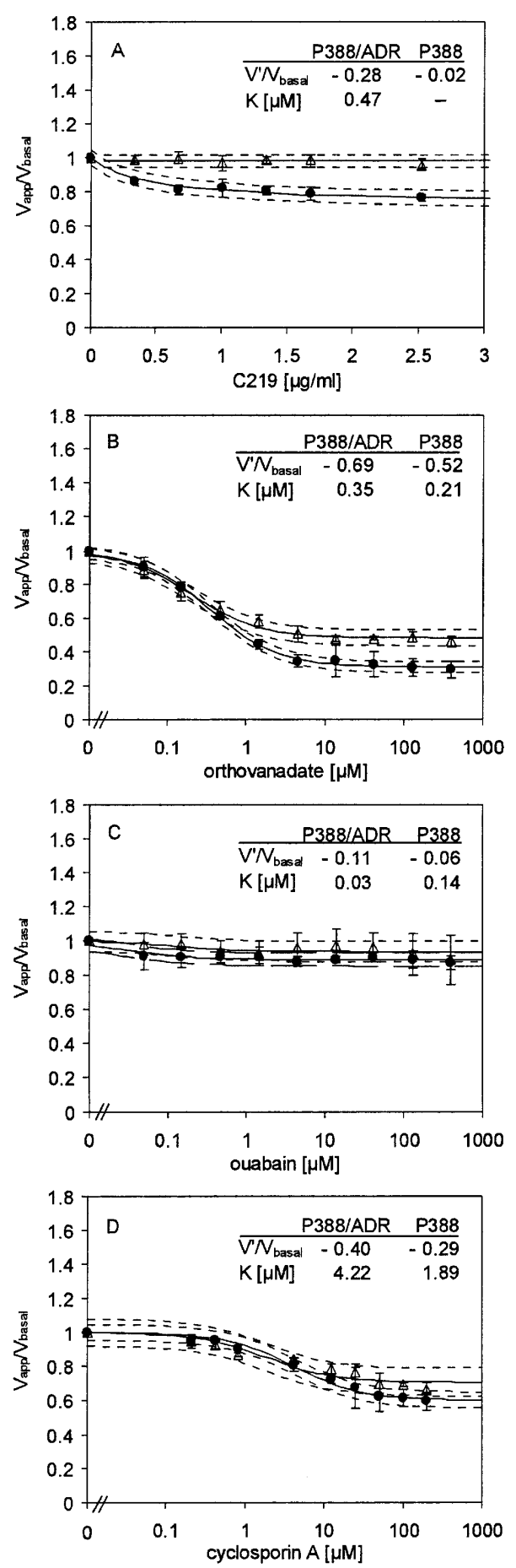

Fig. 3. Influence of ATPase inhibitors on the ATPase activity of rafts. Rafts isolated from P388/ADR cells $(\bullet)$ and from P388 cells $(\Delta)$ were incubated with different concentrations of P-gp antibody C219 (A), orthovanadate (B), ouabain (C), and cyclosporine A (D), respectively, and ATPase activities were determined as described in the text. Data represent mean values and standard deviations from three independent experiments each. The solid lines indicate the fitted functions using Eq. (3) with the $95 \%$ confidence intervals (dotted lines). Fit parameters are shown in the panels.

\section{Influence of Verapamil on the ATPase Activity}

Verapamil is one of the best studied P-gp modulators (33). It activates the P-gp ATPase activity at low concentrations but has an inhibitory effect at higher concentrations (11). To start out, we investigated the influence of verapamil on the ATPase activity of P388/ADR and P388 rafts as well as of crude membranes of P388/ADR cells (Fig. 4 A and B).
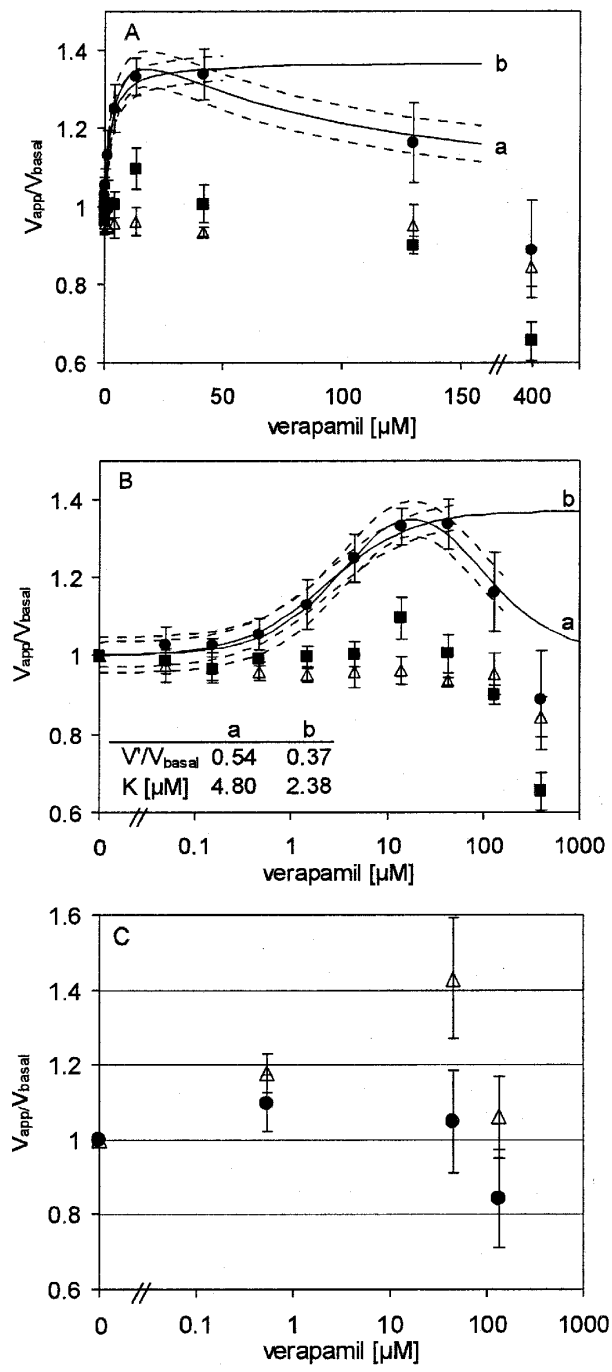

Fig. 4. Influence of verapamil on the ATPase activity of rafts and crude membranes. (A and B) ATPase activities of P388/ADR rafts $(\bullet)$, P388 rafts $(\Delta)$, and P388/ADR crude membranes (ם) were determined at different verapamil concentrations. Data represent mean values and standard deviations from $\geq 3$ independent experiments (rafts) or 3 wells each (crude membranes) in a linear plot (A) and a plot with a logarithmic scale for concentrations (B). The solid lines indicate the fitted functions using Eq. (2) (a; highest concentration excluded from the fit, see "Materials and Methods") and Eq. (3) (b; two highest concentrations excluded) with their $95 \%$ confidence intervals (dotted lines). The fit parameters are shown in panel B. Exclusion of the three highest concentrations and fit with Eq. (2) results in $V^{\prime} / V_{\text {basal }} 0.40$ and $K 2.86 \mu \mathrm{M}$. (C) Influence of verapamil at different concentrations on the ATPase activity of P388/ADR rafts in presence of $2.7 \mu \mathrm{g}$ antibody $\mathrm{C} 219$ per $\mathrm{ml}(\bullet)$ and without antibody $(\Delta)$. Data represent mean values and standard deviations from six independent experiments each. 
Verapamil enhanced the ATPase activity of the P388/ADR rafts at concentrations up to about $100 \mu \mathrm{M}$ and of crude membranes up to about $10 \mu \mathrm{M}$ but had no activating effect on the raft preparations from P388 cells. At higher verapamil concentrations, the ATPase activity was reduced in all three preparations. These results indicate that verapamil at lower concentrations has a specific activating effect on P-gp, whereas at higher concentrations a nonspecific inhibitory effect on ATPases is observed, independently of the presence of P-gp. Similar activity/concentration profiles were found for rafts from mdr1-MDCK and MDCK cells. The profile was bell-shaped in the case of the mdr1-MDCK rafts but no increase in activity was observed with the MDCK rafts (data not shown).

To corroborate further that the verapamil-induced increase in ATPase activity was related to P-gp, ATPase activities of P388/ADR rafts were determined at different verapamil concentrations in the presence of $2.7 \mu \mathrm{g} / \mathrm{ml}$ antibody C219. As shown in Fig. 4C, the antibody significantly reduced the activating effect of verapamil on the ATPase activity of these rafts.

The verapamil concentration-dependent activities of P388/ADR rafts were further analyzed by curve fitting considering verapamil as an activator of the ATPase activity with loss of activation at higher concentrations (Eq. 2). The highest concentration $(400 \mu \mathrm{M})$ was excluded from the fit, being below the basal activity. The fitted bell-shaped curve and the fit parameters $V^{\prime} / V_{\text {basal }}$ and $K_{M}$ are shown in Fig. 4. The fitted parameter $K_{i}$ is of minor interest, as the reduction in activity has been demonstrated to be an additive effect resulting from the inhibition of several ATPases.

To exclude the influence of unspecific effects on the fit parameters, an independent fit of the same activity/ concentration profile was made using the activator function (Eq. 3) excluding verapamil concentrations $>100 \mu \mathrm{M}$. The fit curve and parameters are indicated in Fig. 4. Excluding concentrations $>13 \mu \mathrm{M}$ resulted in similar parameters (see legend to Fig. 4). Equation 2 (activation and loss of activation) revealed $V^{\prime} / V_{\text {basal }}$ and $K_{M}$ values that were within a factor of 1.5 and 2, respectively, of the parameters resulting from Eq. (3) (activation only).

\section{Influence of Known P-gp Activators and an MRP Activator on the ATPase Activity}

Beside verapamil the known P-gp ATPase activators progesterone (11), propranolol (7), and valinomycin (11) as well as indomethacin, which activates the ATPase activity of the multidrug resistance-associated proteins MRP1 and MRP2 in the studied concentration range (34), were tested in the ATPase assay with rafts. The activity/concentration profiles are shown in Fig. 5A-5D. With the known P-gp activators, the typical bell-shaped curves were obtained with P388/ ADR raft preparations, whereas no activating effect on the ATPases of the P388 rafts was observed. Similarly to verapamil, at higher concentrations progesterone and propranolol reduced the activity also in rafts from P388 cells (valinomycin was not investigated). As elaborated with verapamil, fit data plotted in Fig. 5 are based on the activator function (Eq. 3). The corresponding fit values for $V^{\prime} / V_{\text {basal }}$ and $K$ are indi- cated. Indomethacin had no activating effect on the ATPase activity of P388/ADR rafts (Fig. 5D). However, as the other tested compounds, it inhibited the ATPase activity at high concentrations (i.e., above $14 \mu \mathrm{M}$ ).
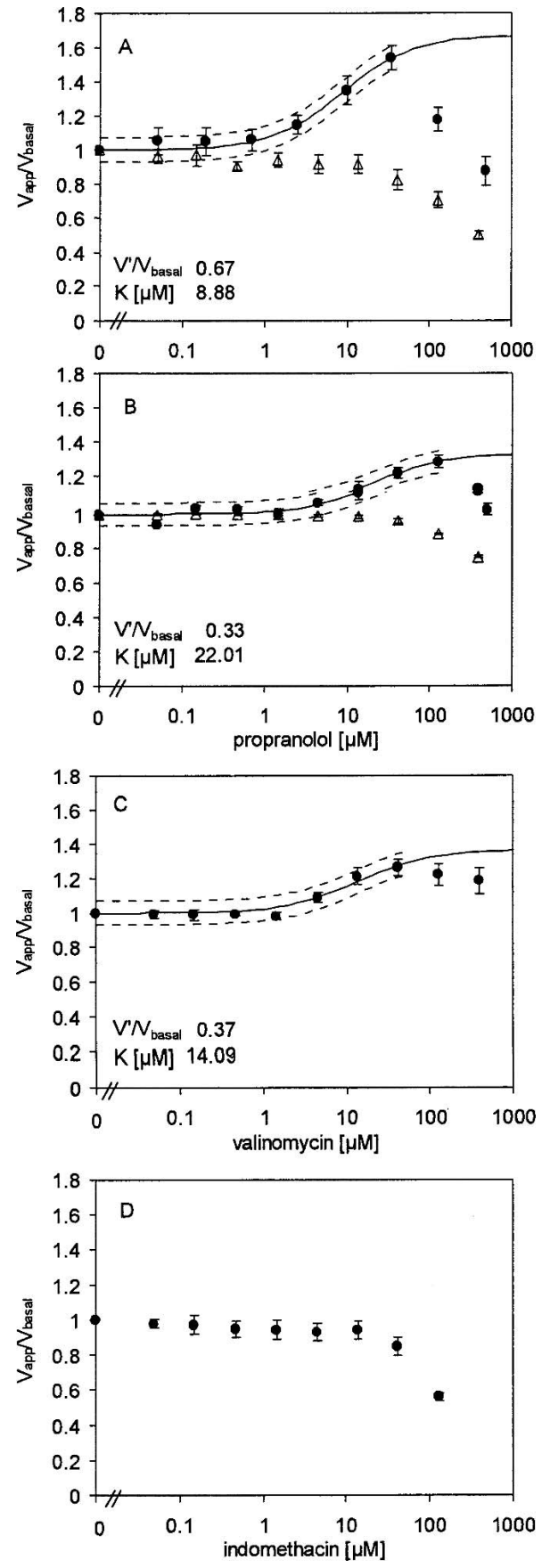

Fig. 5. Influence of (A) progesterone, (B) propranolol, (C) valinomycin, and (D) indomethacin on the ATPase activity of rafts. The ATPase activities at different concentrations of the tested compounds were determined in P388/ADR rafts $(\bullet)$ and P388 rafts $(\Delta$; as indicated). Data represent mean values and standard deviations of three independent experiments each with the fitted functions using Eq. (2) (solid lines; two highest concentrations excluded from the fit, see "Materials and Methods") and their 95\% confidence intervals (dotted lines). The fit parameters $V^{\prime} / V_{\text {basal }}$ and $K$ are shown in the panels. 


\section{DISCUSSION}

Using the cold TritonX-100 extraction method combined with a sensitive ATPase assay, we can show here for the first time that P-gp and other ATPases are functional in isolated rafts of P-gp-overexpressing cells, which expel typical P-gp substrates (35). The raft preparations can be used as straightforward system for the screening of drug-related effects on raft-associated ATPases.

The total basal ATPase activity in our assay with rafts from P388/ADR and P388 cells was between 1 and $2 \times 10^{-4}$ mmol $\mathrm{min}^{-1}$ per $\mathrm{mg}$ protein. This is similar to the published basal ATPase activities of various cell membrane fractions of different types of multidrug-resistant cells, namely the plasma membrane fraction of P-gp-overexpressing CHRB30 cells (36), the microsomal membrane fraction of the tumor cell line CR1R12 (37), and crude membrane vesicles form actinomycin D-resistant chinese hamster lung fibroblasts DC-3F/ADX (11), all revealing activities between 1 and $4 \times 10^{-4} \mathrm{mmol}$ $\min ^{-1}$ per $\mathrm{mg}$ total protein. Reconstitution of purified P-gp into proteoliposomes containing the lipid extract of Escherichia coli led to a basal ATPase activity of $3 \times 10^{-2} \mathrm{mmol}$ $\min ^{-1}$ per mg protein (38) and in a mix of E. coli phospholipids, phosphatidylcholine, phosphatidylserine, and cholesterol to $1.75 \times 10^{-4} \mathrm{mmol} \mathrm{min}^{-1}$ per mg protein (39).

From the partial inhibition of the ATPase activity of P388/ADR rafts by the monoclonal P-gp antibody C219, we conclude that $20 \%$ to $30 \%$ of the basal activity of P388/ADR rafts (in absence of $\mathrm{K}^{+}$and $\mathrm{Ca}^{2+}$ ) is contributed by $\mathrm{P}$-gp. The antibody $\mathrm{C} 219$ has been discussed as a specific inhibitor of the P-gp ATPase by blocking the binding of ATP to its binding sites on the protein $(15,40)$. The antibody-inhibited activity of
P388/ADR rafts corresponds to 2 to $6 \times 10^{-5} \mathrm{mmol} \mathrm{min}^{-1}$ per $\mathrm{mg}$ protein. In the plasma membrane enriched fraction of adriamycin-resistant human breast adenocarcinoma cells MCF7/ADR, C219 reduced the ATPase activity by $50 \%$ in presence of $\mathrm{Na}^{+} / \mathrm{K}^{+}$- and $\mathrm{Ca}^{2+}$-ATPase blockers (15), resulting in a similar P-gp activity of $3.6 \times 10^{-5} \mathrm{mmol} \mathrm{min}^{-1}$ per $\mathrm{mg}$ protein. It remains open how the patterns of ATPases differ between rafts, crude membranes, and plasma membrane enriched fractions. It can be assumed that rafts contain a subfraction of the plasma membrane-located ATPases, as shown here for P-gp. The existence of raft- and nonraft-localized ATPases has been shown for yeast (41). The preparation procedures and ATPase activities of the three systems are summarized in Table I. The preparation of rafts involves less steps than the preparations of the other two systems and the resulting P-gp activity per mg protein is significantly higher in rafts than in crude membranes from the same cells.

Considering the 5 times higher ATPase activity per mg protein in P388/ADR rafts compared to crude membranes and the fraction of this activity that is inhibited by the P-gp antibody C219 (i.e., 20\% in rafts and 10\% in crude membranes, respectively), the ratio between the P-gp ATPase activities per mg protein of the two systems is estimated to be 10. This is in agreement with the about 12 times higher ratio of P-gp to total protein in rafts as compared to crude membranes, indicating that the basal ATPase activity of a P-gp molecule is similar in the two systems.

To get an estimate on the contribution of other types of ATPases than P-gp on the total ATPase activity of P388/ ADR and P388 rafts, different ATPase inhibitors were tested. More than $50 \%$ of the basal ATPase activity in both raft types was inhibited by $>5 \mu \mathrm{M}$ orthovanadate, an inhibitor of several

Table I. Comparison of the Preparations and ATPase Activities of Rafts and Crude Membranes from P388/ADR Cells and of the Plasma Membrane-Enriched Fraction from MCF7/ADR Cells

\begin{tabular}{|c|c|c|c|}
\hline & Rafts of P388/ADR cells & $\begin{array}{l}\text { Crude membranes of P388/ADR } \\
\text { cells }\end{array}$ & $\begin{array}{l}\text { Plasma membrane-enriched } \\
\text { fractions of MCF7/ADR cells } \\
\text { [Ref. (15)] }\end{array}$ \\
\hline \multirow[t]{7}{*}{ Preparation steps } & Cultured cells & Cultured cells & Cultured cells \\
\hline & 20 min incubation with TritonX-100 & Suspension in ATPase buffer & $\begin{array}{l}\text { Suspension in homogenization } \\
\text { buffer }\end{array}$ \\
\hline & \multirow[t]{2}{*}{ Homogenization } & Homogenization & Homogenization \\
\hline & & $\begin{array}{l}\text { Short centrifugation to remove } \\
\text { nuclei and debris }\end{array}$ & $\begin{array}{l}\text { Short centrifugation to remove } \\
\text { nuclei and debris }\end{array}$ \\
\hline & $\begin{array}{l}19 \mathrm{~h} \text { centrifugation on a sucrose } \\
\text { gradient }\end{array}$ & $\begin{array}{l}100 \text { min centrifugation on a } \\
\text { sucrose cushion }\end{array}$ & $\begin{array}{l}18 \text { h centrifugation on a } \\
\text { sucrose gradient }\end{array}$ \\
\hline & \multirow[t]{2}{*}{ Collection of the band } & $\begin{array}{l}\text { Collection of the band } \\
3 \text { times } 15 \text { min washing (soluble } \\
\text { proteins) }\end{array}$ & Collection of the band \\
\hline & & $\begin{array}{l}20 \text { times passage through a } \\
22 \text {-gauge needle }\end{array}$ & $\begin{array}{l}30 \text { min incubation in water to } \\
\text { disrupt vesicles }\end{array}$ \\
\hline Protein yield per $10^{9}$ cells & $0.3 \mathrm{mg}$ & $2 \mathrm{mg}$ & \\
\hline $\begin{array}{l}\text { Mean basal ATPase activity } \\
\text { per mg protein }{ }^{a}\end{array}$ & $\begin{array}{l}1.53 \times 10^{-4} \mathrm{mmol} \mathrm{min}^{-1}\left(0.33 \times 10^{-4}\right. \\
\left.\quad \mathrm{mmol} \mathrm{min}^{-1} ; \mathrm{n}=33\right)\end{array}$ & $\begin{array}{l}3.2 \times 10^{-5} \mathrm{mmol} \mathrm{min}^{-1}\left(0.9 \times 10^{-5}\right. \\
\left.\quad \mathrm{mmol} \mathrm{min}^{-1} ; \mathrm{n}=3\right)\end{array}$ & \\
\hline $\begin{array}{l}\text { Basal ATPase activity per } \\
\text { mg protein assigned to } \mathrm{P}-\mathrm{gp}^{b}\end{array}$ & $\begin{array}{l}3.2 \times 10^{-5} \text { mmol } \min ^{-1}(20 \% \text { of total } \\
\text { basal activity) }\end{array}$ & $\begin{array}{l}3.2 \times 10^{-6} \mathrm{mmol} \mathrm{min}^{-1}(10 \% \text { of } \\
\text { total basal activity) }\end{array}$ & $3.6 \times 10^{-5} \mathrm{mmol} \mathrm{min}^{-1}$ \\
\hline ATPases $^{c}$ & Raft-located ATPases & $\begin{array}{l}\text { Membrane ATPases (rafts and } \\
\text { non-rafts) }\end{array}$ & $\begin{array}{l}\text { Membrane ATPases, enriched } \\
\text { in plasma membrane } \\
\text { ATPases (rafts and nonrafts) }\end{array}$ \\
\hline
\end{tabular}

${ }^{a}$ Standard deviations and number of independent experiments (n) in brackets.

${ }^{b}$ As estimated from the antibody C219-inhibited fraction of the ATPase activity.

${ }^{c}$ ATPases that are expected in the respective fractions. 
types of ATPases $(31,32)$ including P-gp (42). In microsomal membrane vesicles, the ATPase activity was reduced to about $12 \%$ by orthovanadate (37). Cyclosporin $\mathrm{A}$ is frequently used as P-gp inhibitor but inhibits also other ATPases such as $\mathrm{Na}^{+} /$ $\mathrm{K}^{+}$-ATPases $(43)$ and $\mathrm{Ca}^{2+}$-pumps $(44,45)$. One hundred $\mu \mathrm{M}$ cyclosporin A reduced the basal ATPase activity of P388/ ADR and P388 rafts to about $60 \%$ and $70 \%$, respectively. This is in a similar range as shown for crude membranes (11). Only about $10 \%$ of the ATPase activity in P388/ADR and P388 rafts were inhibited by ouabain and therefore assigned to the $\mathrm{Na}^{+} / \mathrm{K}^{+}$-ATPase. From this we conclude that the ATPase activities determined with the raft preparations under our experimental conditions result from the activities of different types of ATPases.

The bell-shaped ATPase activity/concentration profiles are typical for the P-gp activators. The maximal activating effect of verapamil on the ATPase activity of P388/ADR rafts was observed at 10 to $40 \mu \mathrm{M}$, of progesterone around $40 \mu \mathrm{M}$, of propranolol around $130 \mu \mathrm{M}$ and of valinomycin around 40 $\mu \mathrm{M}$. This is in the same range as described for egg phosphatidylcholine proteoliposomes which displayed maximal ATPase activity at $10 \mu \mathrm{M}$ verapamil (46) and for crude membrane vesicles where maximal ATPase activation was found at $30 \mu \mathrm{M}$ verapamil and $60 \mu \mathrm{M}$ progesterone (47). The ATPase activating effect of verapamil was significantly reduced by the P-gp antibody $\mathrm{C} 219$, indicating that the observed activity-changes are associated with P-gp. To conclude, rafts from $\mathrm{P}$-gp overexpressing cells show typical P-gp ATPase activity and provide therefore an ideal system to study the influence of coumpounds on the ATPase activity of the multidrug-resistance protein.

In our assay with $\mathrm{P}$-gp-devoid rafts (i.e., rafts from P388 cells), concentrations of $>130 \mu \mathrm{M}$ verapamil, $>14 \mu \mathrm{M}$ progesterone, and $>14 \mu \mathrm{M}$ propranolol significantly reduced the ATPase activity in the absence of P-gp. The observed inhibitory effect on the ATPase activity in P388/ADR rafts at high activator concentrations is thus not $\mathrm{P}$-gp specific but is at least in part the result of the inhibition of one or more other ATPases. This puts some question marks on the quantitative evaluation of the effects at inhibitory activator concentrations. In consideration of the relatively high concentrations, unspecific effects on the biologic system have to be expected.

The fit parameters for verapamil were in the same range if either activation and inhibition or only activation at the lower concentrations were taken into account (Eq. 2 and Eq. 3 , respectively). Good estimates of the activating effect $\left(V^{\prime} /\right.$ $\left.V_{\text {basal }}\right)$ and of the concentration mediating half maximal effect $\left(K_{M}\right)$ could be made. These parameters are helpful for the comparison of different compounds and to estimate their effect on P-gp under therapeutic conditions. In our study verapamil had the lowest $K_{M}$ of the tested activators (i.e., it was effective at the lowest concentration). $K_{M}$ was between 2.4 $\mu \mathrm{M}$ (fit with Eq. 3) and $4.8 \mu \mathrm{M}$ (fit with Eq. 2), which both are above the therapeutic plasma concentration range of 0.2 to $1.5 \mu \mathrm{M}$ (48). Progesterone activated P-gp most, reaching 1.5 times the basal activity at $40 \mu \mathrm{M}$. The fitted parameters $V^{\prime} /$ $V_{\text {basal }}$ and $K_{M}$ were 0.67 and $8.9 \mu \mathrm{M}$, respectively. Therapeutic and endogenous plasma levels are far below the fitted $K_{M}$, reaching about $50 \mathrm{nM}$ (500 $\mathrm{nM}$ in pregnancy).

The existence and appearance of rafts in cell membranes is a matter of interesting debates (49). For our assay, it is not of primary interest whether the extracted rafts are native do- mains of the cell membranes or whether they assemble in $1 \%$ cold TritonX-100. Extracted rafts of multidrug-resistant cells provide a simple, P-gp-enriched test system and show the characteristic P-gp ATPase activity. They are easily extractable from whole cells. The results with different raft preparations were reproducible, and the assay measuring NADH oxidation using a fluorescence plate reader is relatively sensitive. One preparation of rafts from $10^{9}$ cells $(150$ to $200 \mathrm{mg}$ protein) provides enough material for about 300 kinetic measurements (i.e., three 96-well plates).

\section{CONCLUSIONS}

To conclude, we show here for the first time that cold TritonX-100 insoluble membrane domains of P-gpoverexpressing cells contain different types of active ATPases, display typical P-gp-related ATPase activity, and can be used as an easy screening system for P-gp-interfering compounds.

\section{ACKNOWLEDGMENTS}

We are grateful to Maja Günthert for excellent technical assistance and reading of the manuscript and to Jeannette Burkhardt for her contribution to this work.

\section{REFERENCES}

1. S. V. Ambudkar, S. Dey, C. A. Hrycyna, M. Ramachandra, I. Pastan, and M. M. Gottesman. Biochemical, cellular, and pharmacological aspects of the multidrug transporter. Annu. Rev. Pharmacol. Toxicol. 39:361-398 (1999).

2. T. Litman, T. Skovsgaard, and W. D. Stein. Pumping of drugs by P-glycoprotein: a two-step process? J. Pharmacol. Exp. Ther. 307: 846-853 (2003).

3. G. D. Eytan, R. Regev, G. Oren, and Y. G. Assaraf. The role of passive transbilayer drug movement in multidrug resistance and its modulation. J. Biol. Chem. 271:12897-12902 (1996).

4. A. Seelig. A general pattern for substrate recognition by Pglycoprotein. Eur. J. Biochem. 251:252-261 (1998).

5. J. E. Penzotti, M. L. Lamb, E. Evensen, and P. D. Grootenhuis. A computational ensemble pharmacophore model for identifying substrates of P-glycoprotein. J. Med. Chem. 45:1737-1740 (2002).

6. R. Didziapetris, P. Japertas, A. Avdeef, and A. Petrauskas. Classification analysis of P-glycoprotein substrate specificity. J. Drug Target. 11:391-406 (2003).

7. A. Seelig and E. Landwojtowicz. Structure-activity relationship of P-glycoprotein substrates and modifiers. Eur. J. Pharm. Sci. 12:31-40 (2000).

8. T. Osterberg and U. Norinder. Theoretical calculation and prediction of P-glycoprotein-interacting drugs using MolSurf parametrization and PLS statistics. Eur. J. Pharm. Sci. 10:295-303 (2000).

9. T. Langer, M. Eder, R. D. Hoffmann, P. Chiba, and G. F. Ecker. Lead identification for modulators of multidrug resistance based on in silico screening with a pharmacophoric feature model. Arch. Pharm. Pharm. Med. Chem. 337:317-327 (2004).

10. D. Schwab, H. Fischer, A. Tabatabaei, S. Poli, and J. Huwyler. Comparison of in vitro P-glycoprotein screening assays: recommendations for their use in drug discovery. J. Med. Chem. 46: 1716-1725 (2003).

11. A. Garrigues, J. Nugier, S. Orlowski, and E. Ezan. A highthroughput screening microplate test for the interaction of drugs with P-glycoprotein. Anal. Biochem. 305:106-114 (2002).

12. F. J. Sharom, R. Liu, Q. Qu, and Y. Romsicki. Exploring the structure and function of the P-glycoprotein multidrug transporter using fluorescence spectroscopic tools. Sem. Cell Dev. Biol. 12:257-265 (2001).

13. E. Landwojtowicz, P. Nervi, and A. Seelig. Real-time monitoring 
of P-glycoprotein activation in living cells. Biochemistry 41:80508057 (2002).

14. S. P. Hammerle, B. Rothen-Rutishauser, S. D. Kramer, M. Gunthert, and H. Wunderli-Allenspach. P-Glycoprotein in cell cultures: a combined approach to study expression, localisation, and functionality in the confocal microscope. Eur. J. Pharm. Sci. 12: 69-77 (2000).

15. N. Kokubu, D. Cohen, and T. Watanabe. Functional modulation of ATPase of P-glycoprotein by C219, a monoclonal antibody against P-glycoprotein. Biochem. Biophys. Res. Commun. 230: 398-401 (1997).

16. T. Litman, T. Zeuthen, T. Skovsgaard, and W. D. Stein. Structure-activity relationships of P-glycoprotein interacting drugs: kinetic characterization of their effects on ATPase activity. Biochim. Biophys. Acta 1361:159-168 (1997).

17. S. Ambudkar, I. Lelong, J. Zhang, C. Cardarelli, M. Gottesman, and I. Pastan. Partial purification and reconstitution of the human multidrug-resistance pump: characterization of the drugstimulatable ATP hydrolysis. Proc. Natl. Acad. Sci. USA 89:84728476 (1992)

18. P. Lu, R. Liu, and F. J. Sharom. Drug transport by reconstituted P-glycoprotein in proteoliposomes. Effect of substrates and modulators, and dependence on bilayer phase state. Eur. J. Biochem. 268:1687-1697 (2001).

19. G. D. Luker, C. M. Pica, S. Kumar, D. F. Covey, and D. PiwnicaWorms. Effects of cholesterol and enantiomeric cholesterol on P-glycoprotein localization and function in low-density membrane domains. Biochemistry 39:7645-7650.

20. Y. Lavie, G. Fiucci, and M. Liscovitch. Up-regulation of caveolae and caveolar constituents in multidrug-resistant cancer cells. $J$. Biol. Chem. 273:32380-32383 (1998).

21. M. Demeule, J. Jodoin, D. Gingras, and R. Beliveau. Pglycoprotein is localized in caveolae in resistant cells and in brain capillaries. FEBS Lett. 466:219-224 (2000).

22. J. W. J. Hinrichs, K. Klappe, I. Hummel, and J. W. Kok. ATPbinding cassette transporters are enriched in non-caveolar detergent-insoluble glycosphingolipid-enriched membrane domains (DIGs) in human multidrug-resistant cancer cells. J. Biol. Chem. 279:5734-5738 (2004).

23. M.-A. Ghetie, R. Marches, S. Kufert, and E. S. Vitetta. An antiCD19 antibody inhibits the interaction between P-glycoprotein (P-gp) and CD19, causes P-gp to translocate out of lipid rafts, and chemosensitizes a multidrug-resistant (MDR) lymphoma cell line. Blood 104:178-183 (2004).

24. L. J. Pike. Lipid rafts: bringing order to chaos. J. Lipid Res. 44:655-667 (2003)

25. D. A. Brown and J. K. Rose. Sorting of GPI-anchored proteins to glycolipid-enriched membrane subdomains during transport to the apical cell surface. Cell 68:533-544 (1992).

26. O. H. Lowry, N. J. Rosebrough, A. L. Farr, and R. J. Randall. Protein measurement with the folin phenol reagent. J. Biol. Chem. 193:265-275 (1951).

27. P. Gonzalo, B. Sontag, D. Guillot, and J. P. Reboud. Fluorometric assay of GTPase activity: application to the couple elongation factor eEF-2-ribosome. Anal. Biochem. 225:178-180 (1995).

28. A. Cornish-Bowden. Fundamentals of Enzyme Kinetics, Portland Press Ltd, London, 1995.

29. A. M. Brown. A step-by-step guide to non-linear regression analysis of experimental data using a Microsoft Excel spreadsheet. Comp. Meth. Prog. Biomed. 65:191-200 (2001).

30. F. J. Sharom, R. Liu, Y. Romsicki, and P. Lu. Insights into the structure and substrate interactions of the P-glycoprotein multidrug transporter from spectroscopic studies. Biochim. Biophys. Acta 1461:327-345 (1999).
31. I. R. Gibbons, M. P. Cosson, J. A. Evans, B. H. Gibbons, B. Houck, K. H. Martinson, W. S. Sale, and W. J. Y. Tang. Potent inhibition of dynein adenosinetriphosphatase and of the motility of cilia and sperm flagella by vanadate. Proc. Natl. Acad. Sci. USA 75:2220-2224 (1978).

32. E. Sabbioni, G. Pozzi, A. Pintar, L. Casella, and S. Garattini. Cellular retention, cytotoxicity and morphological transformation by vanadium(IV) and vanadium(V) in BALB/3T3 cell lines. Carcinogenesis 12:47-52 (1991).

33. J. Robert and C. Jarry. Multidrug resistance reversal agents. $J$. Med. Chem. 46:4805-4817 (2003).

34. E. Bakos, R. Evers, E. Sinko, A. Varadi, P. Borst, and B. Sarkadi. Interactions of the human multidrug resistance proteins MRP1 and MRP2 with organic anions. Mol. Pharmacol. 57:760-768 (2000).

35. A. Rosati, L. Candussio, E. Crivellato, F. Klugmann, T. Giraldi, D. Damiani, A. Michelutti, and G. Decorti. Bodipy-FLverapamil: a fluorescent probe for the study of multidrug resistance proteins. Cell. Oncol. 26:3-11 (2004).

36. R. Liu and F. J. Sharom. Site-directed fluorescence labeling of $\mathrm{P}$-glycoprotein on cysteine residues in the nucleotide binding domains. Biochemistry 35:11865-11873 (1996).

37. T. Litman, T. Zeuthen, T. Skovsgaard, and W. D. Stein. Competitive, non-competitive and cooperative interactions between substrates of P-glycoprotein as measured by its ATPase activity. Biochim. Biophys. Acta 1361:169-176 (1997).

38. E. Howard and P. Roepe. Purified human MDR 1 modulates membrane potential in reconstituted proteoliposomes. Biochemistry 42:3544-3555 (2003).

39. K. M. Kerr, Z. E. Sauna, and S. V. Ambudkar. Correlation between steady-state ATP hydrolysis and vanadate-induced ADP trapping in human P-glycoprotein. J. Biol. Chem. 276:8657-8664 (2001).

40. E. Georges, J. T. Zhang, and V. Ling. Modulation of ATP and drug binding by monoclonal antibodies against P-glycoprotein. $J$. Cell. Physiol. 148:479-484 (1991).

41. K. Malinska, J. Malinsky, M. Opekarova, and W. Tanner. Visualization of protein compartmentation within the plasma membrane of living yeast cells. Mol. Biol. Cell 14:4427-4436 (2003).

42. Q. Qu and F. J. Sharom. FRET analysis indicates that the two ATPase active sites of the P-glycoprotein multidrug transporter are closely associated. Biochemistry 40:1413-1422 (2001).

43. M. Younes-Ibrahim, M. Barnese, P. Burth, and M. V. CastroFaria. Inhibition of purified human kidney $\mathrm{Na}+\mathrm{K}+$-ATPase by cyclosporine A: a possible mechanism for drug human nephrotoxicity. Ann. N. Y. Acad. Sci. 986:633-635 (2003).

44. V. Calderaro, M. Boccellino, G. Cirillo, L. Quagliuolo, D. Cirillo, and A. Giovane. Cyclosporine A amplifies $\mathrm{Ca}^{2+}$ signaling pathway in LLC-PK1 cells through the inhibition of plasma membrane $\mathrm{Ca}^{2+}$ pump. J. Am. Soc. Nephrol. 14:1435-1442 (2003).

45. I. G. Bilmen, L. L. Wootton, and F. Michelangeli. The inhibition of the sarcoplasmic/endoplasmic reticulum $\mathrm{Ca} 2+-\mathrm{ATPase}$ by macrocyclic lactones and cyclosporin A. Biochem. J. 366:255-263 (2002)

46. Y. Romsicki and F. J. Sharom. The membrane lipid environment modulates drug interactions with the P-glycoprotein multidrug transporter. Biochemistry 38:6887-6896 (1999).

47. A. Garrigues, A. E. Escargueil, and S. Orlowski. The multidrug transporter, P-glycoprotein, actively mediates cholesterol redistribution in the cell membrane. Proc. Natl. Acad. Sci. USA 99: 10347-10352 (2002).

48. W. A. Ritschel and G. L. Kearns. Handbook of Basic Pharmacokinetics, American Pharmaceutical Association, Washington, DC, 1999.

49. S. Munro. Lipid rafts: elusive or illusive? Cell 115:377-388 (2003). 